\title{
Creative Use of English as Phonetic Markers in Chinese Context
}

\author{
Chuanbin Ni*, Xueli Liu \\ Email address: \\ nichuanbin@263.net (Chuanbin Ni) \\ ${ }^{*}$ Corresponding author
}

School of Foreign Languages and Cultures, Nanjing Normal University, Nanjing, China

To cite this article:

Chuanbin Ni, Xueli Liu. Creative Use of English as Phonetic Markers in Chinese Context. International Journal of Applied Linguistics and Translation. Vol. 5, No. 1, 2019, pp. 1-8. doi: 10.11648/j.ijalt.20190501.11

Received: January 17, 2019; Accepted: February 10, 2019; Published: February 22, 2019

\begin{abstract}
This research explored the linguistic features of English phonetic loanwords in terms of matrix, carrier, recipient and donor, the approaches from a recipient to its corresponding donor and the reasons for the creative use of English as phonetic markers in Chinese context. The following conclusions were obtained: (1) all matrix is grammatical Chinese. The carriers located in the matrix are fixed expressions, or formulaic language; most recipients are made up of two Chinese characters, a few of which are even nonwords in Chinese; Donors are closely related to famous persons, popular brands, pop songs, popular software packages, and films and TV shows, which embody popularity, modernism and prestige. (2) When a recipient is replaced by a donor, the number of Chinese characters combination is not always equal to that of the corresponding donors, for most of two-character combinations will decrease to monosyllabic English phonetic loanwords. In addition, English phonetic loanwords can derivate further both vertically and horizontally. (3) The English phonetic loanwords are used in Chinese context mainly for playful effects, low-level cosmetic effects and the marking effects of multicultural identities.
\end{abstract}

Keywords: Loanwords, English, Chinese, Internet

\section{Introduction}

Globalization brings about free movement of goods, services, people, technology and information. It is due to the free movement of people speaking different languages that using loanwords from the other language is inevitable, since the two or more languages or varieties will interact and influence one another. Generally speaking, loaning a word involves the adoption of the other language and adaption to orthographic, semantic and phonetic features into its own language [1]. Recently, a creative use of English loanwords phonetic markers ('English phonetic loanwords' for short hereafter) in Chinese context has been becoming more and more popular on Internet among Chinese netizens [2-5]. English phonetic loanwords make full adoption of English no adaption to Chinese at all, that is to say, they only use English words directly in Chinese context. Taking "mouth 顿 开 [máo sè dùn kāi]” (茅塞顿开: to an understanding all of a sudden) as an example, the two Chinese characters “茅塞 sè]" are similar to "MOUTH" in pronunciation and are replaced directly as a whole by "MOUTH", which is an
English word and is related to “茅塞” neither in meaning nor in orthography. For the new trend of multilingual practices on China's Internet, this research will explore the linguistic features of English phonetic loanwords, the approaches from English to Chinese and the reasons for the creative use of English as phonetic markers in Chinese context.

\section{Research Methodology}

In order to clearly define the umbrella terms of a loanword, such as matrix, carrier, recipient and donor, "mouth 顿开”'is taken as an example.

EXAMPLE 1: 我是在深思! 刚才才 mouth 顿开 (茅塞顿 开)!

PinYin ${ }^{1}$ : [wǒ shì zài shēn sī! gāng cái cái máo sè dùn kāi! ]

Meaning: I was thinking hard, and came to an understanding all of a sudden a moment ago.

Recipient/donor: 茅塞[máo sè]/MOUTH

Source: http://www.chinasspp.com/brand/113609/

Matrix: Although the alternation of two languages inside and outside a sentence is optional, the distribution of two 
languages, in most cases, is asymmetrical when an intra-sentential loanword occurs. According to Myers-Scotton [6], the dominant language is the Matrix language (Matrix for short hereafter) and the other one is the Embedded Language. Obviously, Matrix language in EXAMPLE 1 is Chinese.

Carrier: It refers to the smallest independent linguistic unit in which English phonetic loanword is located and the unit should be meaningful at the same time. The carrier could be a phrase, sometimes even be the loanword itself. The carrier in EXAMPLE 1 is “茅塞顿开”, which carries the English phonetic loanword "MOUTH" and serves as the smallest, independent and meaningful linguistic unit.

Recipient: It's a sequence or a combination of Chinese characters that is similar to an English phonetic loanword in pronunciation, and is to be replaced by this loanword. “茅塞 [máo sè]" in EXAMPLE 1 is the recipient, which is to be replaced by MOUTH.

Donor: An English word, which is similar to a sequence or a combination of Chinese characters in pronunciation, will be employed to replace the corresponding Chinese characters. "MOUTH" in EXAMPLE 1 is a donor.

The data were collected mainly from four types of online communities [7-8], that is, Cruising Communities (chat-rooms, certain game spaces, to fulfill the relational and recreational needs), Bonding Communities (social forums, to satisfy the relational needs), Geeking Communities (newsgroups, social content sites and services, blogs, to meet the informational needs), and Building Communities (online gatherings about a central and unifying interest). In total, 1572 examples were captured and 276 cases were left for analyzing after the repeated examples were deleted.

\section{Data and Analysis}

\subsection{Linguistic Features of English Phonetic Loanwords}

Matrix: It was found that 276 English phonetic loanwords collected in this research covered all the four types of online communities mentioned by Kozinets [7]. To be more specific, these English phonetic loanwords were frequently used in chat-rooms, game spaces, social forums, social network sites and services, news groups, blogs, online gatherings, and so on and so forth, mainly as linguistic components of 'Top Text' or 'Bottom Text' in an image macro, or as linguistic components of a single phrase, or of a sentence.

Table 1. Image macros selected from WeChat.

\begin{tabular}{|c|c|c|c|c|}
\hline & EXAMPLE 2 & EXAMPLE 3 & EXAMPLE 4 & EXAMPLE 5 \\
\hline Image: & more明奇妙 & sun心病狂 & & \\
\hline Carrier: & 莫名其妙 ～～～～～～ & 丧心病狂 ～～～ & 煎饼果子 & 过桥米线 \\
\hline PinYin: & [mò míng qí miào] & [sàng xīn bìng kuáng] & [jiān bǐng guǒ zǐ] & [guò qiáo mǐ xiàn] \\
\hline Recipient/donor: & 莫/MORE & 丧/SUN & 饼果/BINGO & 米线 MICHEL \\
\hline Meaning: & be rather baffling & become frenzied & homemade Chinese crepe & rice-flour noodles in Yunnan \\
\hline
\end{tabular}

Image Macro: Similar to its predecessor emoticons, an image macro is a broad term used to describe captioned images that typically consist of a picture and a witty message or catchphrase. An image macro is presented to convey feelings or reactions towards another member of the community. Image macros are one of the most prevalent forms on Internet nowadays in China, and some famous instant messaging software packages, such as Tencent $\mathrm{QQ}^{2}$ and $\mathrm{WeChat}^{3}$, have provided their users or netizens with the package of image macros free of charge, and certain packages are specially designed with English phonetic loanwords. Four examples selected from the package of image macros on WeChat are shown in Table 1.

It can be seen from EXAMPLE 2 to EXAMPLE 5 in Table 1 that, the images are different, and some of them are famous cartoon figures, some even real pictures, but English phonetic loanwords are bound to appear in either "Top Text" or "Bottom Text" as other monolingual image macros do.

Single phrase: If an English phonetic loanword is taken as a linguistic component of a single phrase, this single phrase as a carrier could be used independently, and it might most probably be a Chinese idiom, such as “格格 blue” [gé gé bú rù]
(格格不入: be like a round peg in a square hole; Recipient/donor:不入[bù rù]/BLUE ) and “Liar 俐齿” [líng yá lì chǐ](伶牙俐齿: have a glib tongue; Recipient/donor: 伶牙 [líng yá]/LIAR).

Sentence: When a linguistic component is going to be replaced by an English phonetic loanword within a sentence, the linguistic component may be one or two Chinese characters, or even a phrase (EXAMPLE 6), and sometimes it might even be a nonword (EXAMPLE 7), since the replacement of Chinese linguistic components with English words is based on the similarities of their pronunciations.

EXAMPLE 6:这么冷的一周, me more cool 啊 me more cool, 统统穿起来吧!

[zhè me lěng de yī zhōu, mián máo kù ā mián máo kù, tǒng tǒng chuān qĩ lái ba]

Meaning: It's so cold this week. Long johns pants yo! Long johns pants! Everybody should put them on!

Recipient/donor: 棉毛裤[mián máo kù]/ME MORE COOL

Source: http://www.jhnews.com.cn/2014/1202/427625.shtml

EXAMPLE 7: 她成天喝酒, 醉 summer 死啊!

[tā chéng tiān hē jiǔ , zuì shēng mèng š̃ ā]

Meaning: She drinks all day, leading a befuddled life. 
Recipient/donor: 生梦[shēng mèng]/SUMMER

Source: http://www.vccoo.com/v/6wy9rw?source=rss

An analysis of the matrix of English phonetic loanwords used as a linguistic component either in an image macro, in a single phrase, or in a sentence from both grammatical and syntactic perspectives, has shown that the matrix is definitely grammatical Chinese: (1) the grammatical structure of English phonetic loanwords is made up based on the Chinese grammatical rules, taking “me more cool” (棉毛裤[mián máo kù]) in EXAMPLE 6 as an example. The whole Chinese phrase has been replaced fully by three English words ("me", "more" and "cool"), but these words gather together based on Chinese rather than English grammatical rules; (2) the syntactic structure of the sentence containing the English phonetic loanwords is also based on Chinese syntactic rules, such as "mouth 顿开" in EXAMPLE 1. The role of "MOUTH" is to form a phrase, and further the phrase acts as the predicative of the sentence (我是在深思! 刚才才 mouth 顿开!) that should still observe Chinese syntactic rules.

Carrier: According to the statistic results of 276 cases collected in this research, the carriers prone to be replaced by English phonetic loanwords possess some linguistic properties in common, and can be classified into seven types: Chinese idiom $(43.38 \%)$, name of a famous person $(21.02 \%)$, dish name $(18.84 \%)$, lyric of a pop song $(6.16 \%)$, colloquial expression $(5.80 \%)$, verse of a poem $(2.17 \%)$, place name $(0.72 \%)$ and the others $(1.81 \%)$, as indicated in Table 2.

Table 2. Carrier types of English phonetic loanwords.

\begin{tabular}{lll}
\hline Types & Number of cases & Percent \\
\hline Chinese idiom & 120 & $43.48 \%$ \\
Name of a famous person & 58 & $21.02 \%$ \\
Dish name & 52 & $18.84 \%$ \\
Lyric of a pop song & 17 & $6.16 \%$ \\
Colloquial expression & 16 & $5.80 \%$ \\
Verse of a poem & 6 & $2.17 \%$ \\
Place name & 2 & $0.72 \%$ \\
Others & 5 & $1.81 \%$ \\
Total & 276 & $100 \%$ \\
\hline
\end{tabular}

Chinese idiom: Most of Chinese idioms consist of four characters, but the meaning of a Chinese idiom usually surpasses the sum of the meanings carried by the four characters, as Chinese idioms are often intimately linked with the myth, story or historical fact from which they were derived. As such, a Chinese idiom might not follow the usual grammatical structure and syntax of the modern Chinese, and are instead highly compact and synthetic. However, these modern Chinese idioms have been used for many years and are taken as fixed expressions in both spoken and written Chinese. Some linguistic components of these idioms are easy to be replaced by English phonetic loanwords, such as “不可” in “book 思议” [bù kě sī yì] (不可思议: inconceivable; Recipient/donor: 不可 [bù kě]/BOOK) and “奉” in “无可 phone 告” [wú kě fèng gào] (无可奉告: no comments; Recipient/donor: 奉[fèng]/PHONE).

Dish Name: During the period of the Qin and Han Dynasties, Chinese dish names were named by a direct description of the basic information for their major raw materials or cooking methods. Since the Southern and Northern Dynasties, some Chinese dishes have been given fancy names, which might raise the attractiveness of the dishes and make diners happy $[2,9]$. Thus, Chinese dish names nowadays include such extremely rich information as raw materials, cooking methods, tastes, places, inventors, so on and so forth. As a case in point, Pockmarked Lady's Bean Curd (麻婆豆腐[má pó dòu fǔ]) was thus named to honor its inventor, Pockmarked Lady who owned a small restaurant near the Happiness Bridge in a northern suburb of Chengdu, Sichuan Province, China. Although complicated, these Chinese dish names are easy to be remembered and circulated among common Chinese people, even among those foreigners staying in China for a short period of time, for instance, “青椒 rose" [qīng jiāo ròu sī] (青椒肉丝: sliced pork with green pepper; Recipient/donor: 肉丝[ròu sī]/ROSE) and “西 horse 炒鸡蛋” [xī hóng shì chăo jī dàn] (西红柿炒鸡蛋: scrambled egg with tomato; Recipient/donor: 红柿[hóng shì]/HORSE).

Name of a famous person: Modern Chinese personal names consist of a family name, which comes first and is usually but not always monosyllabic, followed by a given name, which is almost mono- or disyllabic. Although there are currently over 4,000 Chinese family names in use in China, the names of famous persons through Chinese history, such as “李Loki” [li lóng jī1 (李隆基: the seventh emperor from 713 to 756 of the Tang Dynasty in China; Recipient/donor: 隆基[lóng jī]/LOKI) and “自 Joey” [bái jū yì] (白居易: a Chinese poet of the Tang Dynasty in China; Recipient/donor: 居易[jū yì]/JOEY), can be remembered by every Chinese people.

Lyric of a pop song : Chinese pop songs have been recognized as a leading conveyor of changing perceptions and as shape of the consciousness of citizenry, serving to focus attention on issues of cultural, moral or even political significance. Although the mode and the melody of a Chinese song could shape its affection, it's the lyric of the pop song that provides the exact context and distinguishes itself and gains prevalence among ordinary Chinese people, particularly among Chinese young people, for example, “爱情bus 你想买，想买就能买”[ài qíng bù shì nǐ xiăng măi, xiăng măi jiù néng măi] (爱情不是你想买, 想买就能买 ${ }^{4}$ : Love is not something that you want to buy, and you can buy. Recipient/donor: 不是[bù shi]/BUS) and “Need 名字, Word 名字, Tired 名字” [nǐ de míng zì, wǒ de míng zì, tā de míng zi] (你的名字, 我的名字, 他的名字 ${ }^{5}$ :Your name, my name, and his name; Recipient/donor: 你的[nǐ de]/NEED; 我 的[wǒ de]/WORD; 他的[tā de]/TIRED).

Colloquial expression: It refers to words or formulaic language used in ordinary language by common people, such as “见的dollar” [jiàn dé duō le] (见得多了: have seen a lot before; Recipient/donor: 多了 [duō le]/DOLLAR) and “笑到 昏死 gucci” [xiào dào hūn sǐ guò qù] (笑到昏死过去: laugh oneself to death; Recipient/donor: 过去 [guò qù]/GUCCI).

Verse of a poem: In Chinese culture, poetry has consistently been held in extremely high regard, often incorporating expressive folk influences filtered through the minds of Chinese literati, and it is the poetry that has provided a format and a forum for expressions of deep emotion both in public and in private, offered an audience of peers, readers, and 
scholars an insight into the inner life of Chinese writers over more than two millennia, during which some of the famous verses will be circulated around the globe, and, furthermore, be handed over from generation to generation, for instance, “Susan 有路勤为径, 学海无涯苦作舟” [shū shān yǒu lù qín wéi jìng, xué hăi wú yá kǔ zuò zhōu] (书山有路勤为径, 学 海无涯苦作舟 ${ }^{6}$ : Diligence is the path to the mountain of knowledge;hard-working is the boat to the endless sea of learning; Recipient/donor: 书山[shū shān]/SUSAN) and “举 头 warming 月, 低头 school 乡” [jǔ tóu wàng míng yuè, dī tóu sī gù xiāng] (举头望明月, 低头思故乡 ${ }^{7}$ :Raising my head, I see the moon so bright; withdrawing my eyes my nostalgia comes around; Recipient/donor: 望 明 [wàng míng]/WARMMING; 思故 [sī gù]/SCHOOL). These two lines are quite familiar to almost every Chinese.

Place Name: Some Chinese place names just refer to certain historical facts; some may relate to physical features of the place, by using the words like HAI or HU (sea or lake), HE (river) or SHAN (mountain), and a few are directly related to compass directions, such as the capital of China, Beijing, literally indicating "the northern capital" [10]. Although having inherited different origins, Chinese place names are constantly stable for a period of time particularly if they are entitled officially [11]. In other words, Chinese place names are fixed expressions for Chinese in a long run. Taking “呼和 hot" [hū hé hào tè] (呼和浩特: Hohhot, the capital city of Inner Mongolia, China; Recipient/donor: 浩特[hào tè]/HOT) as an example, the capital city of Inner Mongolia got this name in 1954 and has been used in China since then.

Others: Sometimes, the carrier might be names of some materials or things, which are common to everyone, for instance, “棉 so tall” [mián shǒu tào] (棉手套: cotton glove; Recipient/donor: 手套 [shǒu tào]/SO TALL).

Recipient: As shown in Table 3, all recipients belong to most frequently used Chinese characters, whose number ranges between 1 and 4 . It is noticeable that most recipients $(33+158=191 ; 69.21 \%)$ are composed of two characters.

Based on the features whether a recipient is an independent Chinese word or not, these 276 recipients can be divided into two types, non Chinese words (two or more Chinese characters do not make up a meaningful combination) and Chinese words. As indicated in Table 3, 33 out of $276(11.96 \%)$ cases are non Chinese words, while 243 cases $(88.04 \%)$ are Chinese words. Among the 243 Chinese words, 74 cases (26.81\%) are composed of one character, 158 cases $(57.25 \%)$ of two characters, 10 cases $(3.62 \%)$ of three characters, and only 1 case $(0.36 \%)$ of four characters.

Table 3. Recipient types of English phonetic loanwords.

\begin{tabular}{llll}
\hline Types & Characters & Cases & Percent \\
\hline Nonwords & 2 & 33 & $11.96 \%$ \\
& 1 & 74 & $26.81 \%$ \\
Words & 2 & 158 & $57.25 \%$ \\
& 3 & 10 & $3.62 \%$ \\
Total & 4 & 1 & $0.36 \%$ \\
\hline
\end{tabular}

As shown in Table 3, even more than one-tenth of the recipients are made up of nonwords, and the role of a recipient of English phonetic loanwords is not to make up the gaps in semantics or in orthography as a traditional English-based loanword acts in general, but to indicate that the combination of Chinese characters shares the pronunciation similar to that of an English word.

Donor: The number of donor syllables was calculated and shown in Table 4. It can be found that the results differ greatly from those obtained for recipients, $65.22 \%$ of the donors are monosyllabic English words, 32.61\% are disyllabic, and only a few $(2.17 \%)$ are trisyllabic.

Table 4. Numbers of donor syllables.

\begin{tabular}{lll}
\hline Syllables & Cases & Percent \\
\hline 1 & 180 & $65.22 \%$ \\
2 & 90 & $32.61 \%$ \\
3 & 6 & $2.17 \%$ \\
Total & 276 & $100 \%$ \\
\hline
\end{tabular}

As for the donor types of English phonetic loanwords, the statistical results were summarized in Table 5. There are six donor types, that is, name of a famous person, of a popular brand, of a pop song, of a popular software package, and of a film or TV show, as well as common English word.

Table 5. Donor types of English phonetic loanwords.

\begin{tabular}{lll}
\hline Types & Cases & Percent \\
\hline Name of a famous person & 91 & $32.97 \%$ \\
Name of a popular brand & 66 & $23.91 \%$ \\
Name of a pop song & 41 & $14.86 \%$ \\
Name of a popular software package & 22 & $7.97 \%$ \\
Name of a film or TV show & 19 & $6.88 \%$ \\
Common English word & 37 & $13.41 \%$ \\
Total & 276 & $100 \%$ \\
\hline
\end{tabular}

Name of a famous person: 91 cases out of 276 (32.97\%) employ famous persons' names to replace the Chinese characters which are similar in pronunciation, as Eason in “Eason 不吭” [ȳ̄ shēng bù kēng] (一声不吭: keep one's mouth shut; Recipient/donor: 一声 [ȳ̄ shēng]/EASON) and Tony in “Tony 带水” [tuō ní dài shuǐ] (拖泥带水: do things sloppily; Recipient/donor: 拖泥[tuō ní ]/TONY). Eason Chan (1974- ) is a Hong Kong singer and actor while Tony Allen (1982- ) is an American professional basketball player for the Memphis Grizzlies of NBA.

Name of a popular brand: 66 cases (23.91\%) use the names of popular brand, for example, Muji in “呆若 muji” [dāi ruò mù jī]（呆若木鸡： dumb as a wooden chicken; Recipient/donor: 木鸡[mù jī]/MUJI) and Benz in “Benz 所措”, [bù zhī suǒ cuò] (不知所措: at a loss; Recipient/donor: 不知 [bù zhī]/BENZ). Muji is a Japanese retail company which sells a wide variety of household and consumer goods, while Benz is a global automobile manufacturer and a division of the German company Daimler AG.

Name of a pop song: Sometimes, the names of pop songs (41 cases; $14.86 \%$ ) are used to serve as a donor. Taking 'Baby' in 'baby 无耻' [bēi bǐ wú chǐ] (卑鄙无耻: mean and shameless; Recipient/donor: 卑鄙[bēi bǐ]/BABY) and "Blow" in “滴水 blow" [dī shuǐ bù lòu] (滴水不漏: make sure that not a single 
drop leaks out. Recipient/donor: 不漏[bù lòu]/BLOW) for instance, "Baby" is a pop song by a Canadian recording artist Justin Bieber, and "Blow" is a pop song by an American recording artist and song writer Kesha from her first extended play.

Name of a popular software package: Occasionally, the names of popular software packages (22 cases; 7.97\%) might be borrowed to replace the Chinese characters sharing similar pronunciations, such as "Word" and "Excel” in “你伤害了 Word, 还 Excel 而过” [nǐ shāng hài le wǒ, hái yī xiào ér guò] (你伤害了我, 还一笑而过 ${ }^{8}$ : You hurt me, and laughed it off; Recipient/donor: 我[wǒ]/WORD; 一笑[yī xiào]/EXCEL) and “LOL” in “笑不 lol 齿” [xiào bù lù chî] (笑不露齿: smile without showing teeth; Recipient/donor: 露[lù]/LOL). "Word" and "Excel" are software packages developed by Microsoft for Windows, macOS, Android and iOS; LOL (League of Legends) is a multiplayer online battle arena video game developed and published by Riot Games for Microsoft Windows and macOS.

Name of a film or TV show: Under certain circumstances, the Chinese characters with the similar pronunciation to English words would be replaced by English names of a film or TV (19 cases; 6.88\%), for example, "Sherlock" in “麻辣 sherlock 虾”, [má là xiăo lóng xiā] (麻辣小龙虾: hot and spicy crayfish; Recipient/donor: 小龙[xiăo lóng]/SHERLOCK) and “Whistle” in “whistle 欲为” [wéi suǒ yù wéi] (为所欲为: do whatever they want; Recipient/donor: 为 所 [wéi suǒ]/WHISTLE). "Sherlock" is a crime drama television series based on Sir Arthur Conan Doyle's Sherlock Holmes detective stories, while "Whistle" is a Japanese manga series written and illustrated by Daisuke Higuchi, which was adapted into a 39-episode anime television series.

Common English word: Of course, some common English words could also be used to act as donors, such as "farming" in “四大 farming” [sì dà fā míng] (四大发明: four great inventions of ancient China; Recipient/donor: 发明 [fā míng]/FARMING) and "one year" in “什么 one year" [shí me wán yì (什么玩意: What the hell; Recipient/donor: 玩意 [wán yì]/ONE YEAR).

\subsection{Approaches from a Recipient to Its Corresponding Donor}

A comparison of the results of recipients' number of Chinese combination with those of donors' number of syllables indicates that most of the Chinese combinations are two-character Chinese words, whereas most donors are monosyllabic. In other words, when a Chinese recipient is replaced by a donor with a similar pronunciation, the number of Chinese characters is not always equal to that of the corresponding donors.

To analyze the general conditions of the transformation from a recipient to a corresponding donor, the statistical results listed in Table 6 indicate: (1) 165 cases (73 for 1 character, 87 for two characters and 5 for 3 three characters) out of $276(59.78 \%$ ) are equal; (2) 109 cases (103 for two characters, 5 for three characters, 1 for four characters, and $39.49 \%$ in total ) will decrease; and (3) only 2 cases $(0.73 \%)$ increase in number of syllables. That is to say, more than a half of the cases stay equal in syllable's number in the process from a recipient to a donor, and nearly one-third of the cases will decrease and few will increase in syllable's number.

Table 6. Recipients and their corresponding donors.

\begin{tabular}{|c|c|c|c|c|c|}
\hline Recipient & & & Donor & & \\
\hline Characters & Cases & Percent & Syllables & Cases & Percent \\
\hline \multirow{3}{*}{1} & \multirow{3}{*}{74} & \multirow{3}{*}{$26.81 \%$} & Equal to 1 syllable & 73 & $98.65 \%$ \\
\hline & & & Increase to 2 syllables & 1 & $1.35 \%$ \\
\hline & & & Sum & 74 & $100 \%$ \\
\hline \multirow{4}{*}{2} & \multirow{4}{*}{191} & \multirow{4}{*}{$69.20 \%$} & Decrease to 1 syllable & 103 & $53.93 \%$ \\
\hline & & & Equal to 2 syllables & 87 & $45.55 \%$ \\
\hline & & & Increase to 3 syllables & 1 & $0.52 \%$ \\
\hline & & & Sum & 191 & $100 \%$ \\
\hline \multirow{5}{*}{3} & \multirow{5}{*}{10} & \multirow{5}{*}{$3.62 \%$} & Decrease to 1 syllable & 4 & $40 \%$ \\
\hline & & & Decrease to 2 syllable & 1 & $10 \%$ \\
\hline & & & Equal to 3 syllables & 5 & $50 \%$ \\
\hline & & & Increase to 4 syllables & 0 & $0 \%$ \\
\hline & & & Sum & 10 & $100 \%$ \\
\hline 4 & 1 & $0.36 \%$ & Decrease to 2 syllable & 1 & $100 \%$ \\
\hline Total & 276 & $100 \%$ & -- & 276 & - \\
\hline
\end{tabular}

To analyze the specific conditions of the transformation, the results suggest: (1) for the recipients with 1 character, 73 cases out of $74(98.65 \%)$ are equal and only 1 case increases in the syllable's number; (2) for those with 2 characters, 103 cases $(53.93 \%)$ out of 191 decrease, 87 cases $(45.55 \%)$ are equal and only 1 case $(0.52 \%)$ increases in the syllabic number; and (3) for those with three characters, 4 cases $(40 \%)$ out of 10 decrease to 1 syllable and 1 case $(10 \%)$ decreases to 1 in the syllable's number, and 5 cases $(50 \%)$ are equal.

It is interesting to notice the transformation of the typical recipients of two Chinese characters. The results in the current research present that more than a half of the two Chinese characters decrease to one syllable, less than a half keep unchanged in the number of syllables.

It is also intriguing to find the further derivation in the transformation of English phonetic loanwords from recipients to corresponding donors, which can be viewed with two dimensions. Vertically, more new English phonetic loanwords might be made on the basis of one or two key linguistic components previously employed in one English phonetic 
loanword, which has been well-accepted. For instance, "me more cool" in EXAMPLE 6 has two key linguistic components, one is "me more" (棉毛[mián máo], cotton and woolen) and the other is "cool" (裤[kù], pants), and basing on these two key linguistic components, plenty of words can be created, such as “me more say" [mián máo shān] (棉毛衫: cotton sweater; Recipient/donor: 棉 毛 衫 [mián máo shān]/ME MORE SAY), “more cool” [máo kù] (毛裤: long woolen underwear; Recipient/donor: 毛裤 [máo kù]/MORE COOL), "chill cool" [qiū kù] ( 秋 裤 : long johns; Recipient/donor: 秋裤[qiū kù]/CHILL COOL), "young more

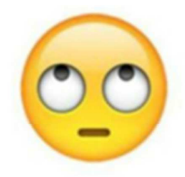

无Fuck说

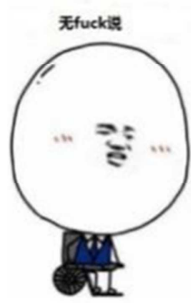

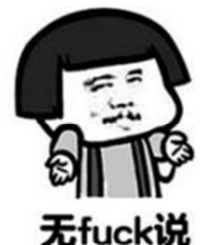

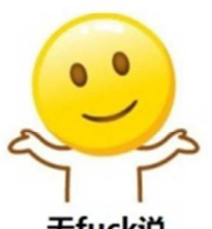

cool" [yáng máo kù](羊毛裤: woolen pants; Recipient/donor: 羊毛裤[yáng máo kù]/YOUNG MORE COOL), and “care down cool" [kāi dāng kù] (开裆裤: open-crotch pants; Recipient/donor: 开裆裤 [kāi dāng kù]/CARE DOWN COOL). Horizontally, one English phonetic loanword may be presented in different forms and styles. Taking “无fuck 说” [wú huà kě shuō] (无话可说: can say nothing more; Recipient/donor: 话可[huà kě]/FUCK) as an example, there are at least eight different image macros used in Chinese context, as indicated in the following image macros.

Figure 1. Different image macros of “无FUCK 说”.

\subsection{Reasons for the Creative Use of English Phonetic Markers}

The reasons for using phonetic markers of English in Chinese context might differ from person to person, and from case to case, but once gathering together as a group, they may share something in common.

For playful effects: Language play is the manipulation, conscious or unconscious, of elements of language and speech, in relation to one another and/or in relation to the social and cultural contexts of their use [12]. English is being used in very original and playful ways in China, both in the exploration of new ways of expression as semiotic elements in terms of an ideological construct relating to a cultural narrative of the Western world, and as a functional tool to express new meanings and serve new language-specific purposes [13-14]. Bilingual language play often involves creative mixing of multiple languages and language varieties, with creating new patterns and new realities where there were none before. In the case of English phonetic loanwords in Chinese context, it is often found to simply render some English words similar to Chinese characters in pronunciation, inviting the readers to figure out the meanings of these English words in such puzzle like transliteration riddles which are not too difficult to be understood. Once understood, playful effect works. By so doing, the strategy of such puzzle like transliteration riddles as English phonetic loanwords can be seen as uniting the users and the readers in comedic engagement [15].

For low-level cosmetic effects: In Internet communication, netizens often intend to use English loanwords for special purposes, including the desire to use a euphemism, to create an eye-catching phrase, or to induce a desired emotional response [16]. As pointed out by Rivlina [17], playful throwing of English into Chinese helps to create a lighthearted and relaxed conversational environment, and contributes to such low-level cosmetic effects as eye-catching, attention-getting, or memory-facilitating.

For the marking effects of multicultural identities: Internet represents a language contact situation of unprecedented scale, where different languages might juxtaposition with each other in new ways to satisfy the creative needs of netizens, especially the needs of those young bilinguals to blend the multicultures of the local and global, the traditional and modern, and the indigenous and foreign, which can be met neither effectively nor efficiently by means of a single, separate linguistic system [18-19]. For the young netizens in China, blending Chinese with English has become a part of their everyday communication practices as they build multicultural identities, transform the traditional social relationships and practice their social responsibilities, by using new communication technologies as well as their linguistic and cultural repertoires [20]. Therefore, English phonetic loanwords may well serve the function of marking the netizens with individual style of multicultures in modern times [21-22].

\section{Conclusion}

This research explored the linguistic features of English 
phonetic loanwords in terms of matrix, carrier, recipient and donor, investigated the process of English phonetic loanwords from English to Chinese, and analyzed the reasons for using English phonetic loanwords in Chinese context. Findings have fallen into three aspects, namely, (1) all matrix is grammatical Chinese. The carriers refer to the fixed expressions or formulaic language. Most recipients are two-character Chinese words and a few are even nonwords, and donors often have a close relation to persons, brands, songs, software packages, as well as films and TV shows with popularity, modernism and prestige. (2) The number of recipients is not always equal to that of the corresponding donors since most of the two-character combinations are replaced by monosyllabic English phonetic loanwords. Besides, English phonetic loanwords can derivate further in both vertical and horizontal ways. (3) These English phonetic loanwords are used in Chinese context as amusement, low-level cosmetic effects and markers of multicultural identities.

\section{Acknowledgements}

My very special thanks must go first and foremost to the members of our research team for collecting the data on Internet. This study was supported by The National Social Science Foundation of China (Fund Grant: No. 16BYY069). I also thank Helen Blake for her helpful stylistic suggestions for the manuscript.

\section{Notes}

1. PinYin is a modern system of transcription of the Mandarin pronunciation of Chinese characters (as opposed to Cantonese or some other dialect, which all share the same written Chinese characters) that uses Roman alphabet letters and lexical tone transcriptions. It is taught to both non-native speakers and to Chinese first graders in order to provide a stronger grasp of the tones, phoneme segmentations, and phoneme combinations represented by Chinese characters.

2. QQ, also known as Tencent QQ, is an instant messaging software service developed by the Chinese company Tencent Holdings Limited. QQ also offers services that provide online social games, music, shopping, microblogging, movies, and group and voice chat. The software uses a logo of a small penguin wearing a red scarf. As of April 2014, over 200 million simultaneous online QQ users were recorded. At the end of June 2016, there were 899 million active QQ accounts.

3. WeChat is a mobile text and voice messaging communication service developed by Tencent in China, first released in January 2011. The APP is available on Android, iPhone, BlackBerry, Windows Phone platforms. WeChat has over 600 million downloads, with 270 million active users. This makes it one of the most popular social APPs in the world. WeChat was built and owned by Tencent Holdings Limited, which is China's first globally known Internet brand.

4. Lyrics of a pop song "You Can Not Buy Love", first sung by Gong Linna (1975-), a Chinese female singer.

5. Lyrics of a pop song "Lylian", written and sung by Song Dongye (1987- ), a Chinese male ballad singer.
6. Verses of The Broadens Wise Text (Section: Encouraging Learning), written by Han Yu (768-824). Han Yu was a Chinese writer, poet, and government official of the Tang dynasty who significantly influenced the development of Neo-Confucianism.

7. Verses of On A Quiet Night, written by Li Bai (701-762), also known as Li Bo. He was a Chinese poet acclaimed from his own day to the present as a genius and a romantic figure who took traditional poetic forms to new heights.

8. Lyrics of a pop song "Laughed It Off" presented by $\mathrm{Na}$ Ying (1967- ), a Chinese vocalist. She is considered as one of the best present-day female pop singers.

\section{References}

[1] Kim, H. 2009. Korean adaptation of English affricates and fricatives in a feature-driven model of loanword adaptation. In A. Calabrese \& L. Wetzels (eds). Loan Phonology. Amsterdam: John Benjamins Publish Company. pp 155-180.

[2] Zhang, W. 2015. Multilingual creativity on China's internet. World Englishes, 34 (2), 231-246.

[3] Sun, M. \& Tong, M. 2016. The grammatical analysis and social function of Chinese-English code-switching in TV advertisements. Foreign Language Research, 191 (4), 105-109.

[4] Xu, M. \& Tian, C. 2017. 'NBA' Chinese or English?: The current situation of English lettered words in Chinese. English Today, 33 (4), 33-39.

[5] Yu, X. \& Liu, A. 2017. The use and role of Chinese-English code-switching in internet discourse. Overseas English, 17 (1), 215-216.

[6] Myers-Scotton, C. 2001. The matrix language frame model: Developments and responses. Journal of Mass Spectrometry, $21(3), 165-175$.

[7] Kozinets, R. 2010. Netnography: Doing ethnographic research online. New York: Sage Publications.

[8] Botha, W. 2017. The use of English in the social network of a student in south china. English Today, 33 (4), 19-29.

[9] Li, S. 2015. English in the linguistic landscape of Suzhou. English Today, 31 (1), 27-33.

[10] Niu, R. 1993. The Culture of Chinese Place Names. Beijing: The Chinese Overseas Publishing House.

[11] Zhang, J., Lin, N. \& Li, D. 2012. Mosuos' awareness of taxonomic relations in word associations, lexicon decisions and semantic categorizations. Scandinavian Journal of Psychology 53 (3). 191-199.

[12] Sherzer, J. 1993. On puns, comebacks, verbal dueling, and play languages: speech play in Balinese verbal life. Language in Society, 22 (2), 217-233.

[13] Scherling, J. 2016. The creative use of English in Japanese punning. World Englishes, 35 (2), 276-292.

[14] Xu, M. \& Tian, C. 2017. So many tuhao and dama in china today. English Today, 33 (2), 2-8. 
[15] Zhang, R. 2015. History of Food Culture in China. New York: SCPG Publishing Corporation.

[16] Stanlaw, J. 2010. Japanese-English Language and Culture Contact: How Much English Is Found in Japanese, How Is It Used, and Why Should Students and Teachers Care? Journal of Canadian Association for Japanese Language Education, 11 (1), 40-60.

[17] Rivlina, A. 2015. Bilingual creativity in Russia: English-Russian language play. World Englishes, 34 (3), 436-455.

[18] Kathpalia, S. \& Kenneth, O. 2015. The use of code-mixing in
Indian billboard advertising. World Englishes, 34 (4), 554-575.

[19] Seargeant, P. \& Caroline, T. 2011. English on the internet and a 'post-varieties' approach to language. World Englishes, 30 (4), 496-514.

[20] Zhang, W. 2012. Chinese-English code-mixing among China's netizens. English Today, 28 (3), 40-52.

[21] Coupland, N. 2007. Style: Language variety and identity. Cambridge: Cambridge University Press.

[22] Hoffer, B. 2002. Language borrowing and language diffusion: an overview. Intercultural Communication Studies, XI (4), $1-37$. 